Journal of Engineering and Applied Sciences 14 (19): 7179-7186, 2019

ISSN: 1816-949X

(C) Medwell Journals, 2019

\title{
Analysis of the Development on Deconcentration in Indonesia
}

\author{
${ }^{1}$ Rahyunir Rauf, ${ }^{1}$ Yusri Munaf, ${ }^{2,3}$ Sharifah Zarina Syed Zakaria, \\ ${ }^{3}$ Kadir Arifin and ${ }^{4}$ Muhammad Rizal Razman \\ ${ }^{1}$ Faculty of Social and Political Studies (FISIPOL), Universitas Islam Riau (UIR), \\ Jalan Kaharuddin Nasution, No 113, Simpang Tiga Marpoyan, 28284 Pekanbaru, Riau Indonesia \\ ${ }^{2}$ Research Centre for Environmental, Economic and Social Sustainability (KASES), \\ Institute for Environment and Development (LESTARI), \\ ${ }^{3}$ Social, Environmental, Developmental Sustainability Research Centre (SEEDS), \\ Faculty of Social Sciences and Humanities (FSSK), \\ ${ }^{4}$ Research Centre for Sustainability Science and Governance (SGK), \\ Institute for Environment and Development (LESTARI), Universiti Kebangsaan Malaysia (UKM), \\ 43600 Bangi, Selangor, Malaysia
}

\begin{abstract}
Discussions about local governance have always been very interesting to discuss and debate, especially with the increasingly critical and dynamic conditions of regional communities, requiring the government and local governments to always carry out innovations in the administration of regional governance. In essence, regional government in Indonesia is an integral part of the national government system because local government is a subsystem of the national government system, so that, elements of national government with elements of regional government constitute an inseparable unity, especially within the framework of the Unitary Republic of Indonesia. In the implementation of regional governance in Indonesia, there are three principles, namely, deconcentration, decentralization and co-administration. In this study, only discussed about deconcentration. Deconcentration is the delegation of authority from the government to government officials in the region and to vertical agencies. The development of the concept of deconcentration in Indonesia can be seen from 4 Laws on Regional Government in Indonesia, namely, Law No. 5 Year 1974, Law No. 22 Year 1999, Law No. 32 Year 2004 and Law No. 23 Year 2014. The regulation on deconcentration in the four laws is different from each other. This study uses library techniques in describing and explaining the development of deconcentration in Indonesia. In its implementation in Indonesia deconcentration is more dominant in Law No. 5 Year 1974 (the reign of the New Order) and the application of deconcentration is very small at the time of Law No. 22 of 1999 (post-reform). Whereas at the time of Law No. 32 of 2004 and Law No. 23 of 2014 the existence of deconcentration is very balanced with concentration.
\end{abstract}

Key words: Local government, deconcentration, decentralization, central government representatives, vertical agencies, library techniques

\section{INTRODUCTION}

Government is an organisation or institution that is given legitimacy by the people to regulate and manage affairs and the interests of the community and is equipped with the state equipment (Razman et al., 2009a; Razman et al., 2014; Wasistiono, 2009). In addition, government is an organisation that has the authority to provide public services and is obliged to give civil services for everyone through governmental institutions to every single member of the communities (Khairil et al., 2017; Yudoyono, 2003; Razman and Azlan, 2009).
Furthermore, government is also a multi-process system that aims to fulfill and protect various needs as well as demands governed by public services and also the civil service process (Khairil et al., 2017; Yudoyono 2003, Razman et al., 2015).

\section{MATERIALS AND METHODS}

Deconcentration system: The background of the deconcentration system was held because not all central government affairs could be handed over to local governments, according to the principle of

Corresponding Author: Rahyunir Rauf, Faculty of Social and Political Studies (FISIPOL), Universitas Islam Riau (UIR), Jalan Kaharuddin Nasution, No 113, Simpang Tiga Marpoyan, 28284 Pekanbaru, Riau Indonesia 
decentralization (Kertapraja, 2010; Razman et al., 2010). Consideration and purpose of the implementation of this deconcentration principle based on the following subject matters as:

- Increasing the efficiency and effectiveness of governance, development management and service to the public interest

- The maintenance of social and socio-cultural communication in the state administration system

- Maintaining harmony in the implementation of national development

- Maintaining the integrity of the Unitary Nation (Kertapraja, 2014; Razman et al., 2009b, 2009b, c)

The existence of deconcentration is one form of the concept of decentralization as stated by Kertapraja (2014) that: "In this principle, an authority is submitted by the central government to elements of the regional government. This process is in two ways, namely, first with delegations to their officials in the regions (deconcentration) or second with devolution to regional autonomy bodies. However, the content and freedom of authority and consequences of the transfer of such authority to the regional autonomy bodies are not explained".

The concept of the "offices of administration area" is an area device outside the head office. To the officials by the central department delegated an authority and responsibility in certain areas of affairs that act as representatives of the central department to carry out certain functions of an administrative nature without receiving full submission of authority (final authority). The final responsibility remains with the central department (the arrangement is administrative and nature and implies no transfer of final authority from the ministry, whos responsibility continues (Rosidin, 2010).

The concept of deconcentration according to Rosidin (2010), "That the delegation of authority from the government or the regional head or the head of the upper-level vertical agency to officials in the region which includes: the delegation of authority from the government apparatus to a higher level to other apparatuses at one level of government is called horizontal deconcentration. The delegation of authority from the government or from the government apparatus which is higher in level to other apparatus in the lower levels of government is called vertical deconcentration. In the framework of implementing the deconcentration principle, the territory of the Unitary State of the Republic of Indonesia is divided into the provinces and capitals of the country. The province's territory is divided into regency and city areas. Then the districts/cities are divided into sub-districts. The application of this kind of deconcentration principle is called territorial deconcentration.

In essence deconcentration, according to Sunindhia and Widiyanti (1987), namely, "Delegation of authority to subordinate central government officials who are in the area (in the central area) and each has a position area or area of office, according to hierarchical levels namely authority or right to act and take decisions on their own initiative (delegation of authority) regarding its territories. All that is handed down is only the authority to act and the authority to make decisions while the responsibility of the community (DPR) remains in the hands of the highest officials.

Deconcentration in general is a delegation of authority from the central government to central government officials in regions or vertical agencies in the regions to carry out central government affairs in the regions. Deconcentration is essentially only a delegation of authority, not in the form of giving or submitting affairs to the region by the central government, so that, the authority still remains with the central government which acts as the delegate of authority. Whereas those who accept the transfer of authority from the central government are central government officials in regions such as Governors or Vertical Agencies. Vertical agencies are central government agencies in the regions to carry out central government affairs in the regions, so that, vertical agency employees are central government employees who are regulated by the central government and paid through the State Budget (APBN) (Wasistiono, 2009; Emrizal and Razman, 2010).

In essence, matters through the deconcentration principle are carried out by central government officials in the regions and assisted by the central government apparatus in the regions, so that, if the principle of deconcentration is carried out the regional office is a controversy as stated by Wasistiono (2009), that "Deconcentration should be carried out by the central government apparatus that is outside the capital of the country. If implemented by the Regional Office as a tool for decentralization, it will lead to confusion of implementation with the principle of co-administration".

In the implementation of the deconcentration principle, it is financed through APBN and is accounted for again to the central government. As stated by Rosidin (2010), namely: "Budgeting for the implementation of deconcentration is carried out in accordance with the provisions applicable to the APBN. The budget for the implementation of the deconcentration principle is part of the budget of the department/non-departmental government institution concerned. Further provisions 
regarding budgeting are stipulated by the decision of the finance minister by taking into account the considerations of other relevant technical ministers (Rosidin, 2010).

The implementation of the deconcentration principle according to Rosidin (2010), on regards of the authority delegated which entirely the affairs of the central government while those that are bestowed are merely executors. Thus, deconcentration is the responsibility of the central government while regions in this case are provinces, only given authority because of their position as representatives of the central government. The governor, in addition to implementing the principle of decentralization, also implements deconstruction. The magnitude and content of deconcentration must be close to the interests of the community and be meaningful as an effort to maintain and strengthen the unity and integrity of the nation and the integrity of the Unitary Republic of Indonesia increase empowerment, foster community initiative and creativity and national awareness (Rosidin, 2010; Rauf, 2016).

\section{RESULTS AND DISCUSSION}

Analysis of the development on deconcentration in Indonesia: Indonesia is essentially a large country which in its state system arrangement adheres to a "democratic system", in a democratic system the existence of the people and its position in the state must be placed as "the highest sovereign holder". One characteristic of a democratic country is the position of the people as the owners of the government or also called the people as government shareholders. The existence of "people" in democratic countries is placed as one of the elements that must be included in policy making, especially, policies in determining national leaders and regional leaders through legislative elections, presidential elections and regional head general elections (Sarundajang, 2005; Ali et al., 2017). In relation to the democratic system adopted by the Republic of Indonesia in its state system, according to Sarundajang (2005), that "One of the characteristics of a country in the form of a democratic system is the position of the people as the owners of government elements (people own government)." As the owner of the government, the highest sovereignty is in the hands of the people. The people are actively involved in helping government tasks and have the authority to carry out social control over the running of governance and development. Consequently, the government must try to please its people, so that, the people can feel that the management of the government has been done well. This will lead to greater levels of popular support for the government (Sarundajang, 2005; Ali et al., 2017; Razman,
2014, 2015). Further said by Sarundajang (2005), that "In reality in Indonesia throughout the journey of the New Order government, the existence of the people who are in a weak position (strong state and weak society) wherein this condition the values of popular sovereignty experienced a process of erosion due to the power of the new order government." Because in the reign of the new order "people's sovereignty" was still considered a concept of value only (Sarundajang, 2005).

In reality, the position of the people still in a weak position has caused the nature of their bargaining power to the government is very limited, the people cannot implement their sovereignty in a government with a democratic system. The people as if no longer have alternative choices but must always obey and submit to various policies of the central and regional governments because in reality groups that oppose the government always face various problems, especially, problems at the level of local government (Marbun, 2005). Regarding the existence of regional government in Indonesia, Marbun (2005), stated that, "Given that a country is a giant organization that must submit to the philosophy of the state and the mechanism of organisms, it is a logical consequence if the organization (management) of the state organization or government is divided into levels, according to the size of an organization. The Republic of Indonesia is a large country, both in terms of area and population, so in terms of the complexity of its organization, it is natural that its organizational structure recognizes the division of power, the delegation of control power is centralized and diffused (Marbun, 2005).

The makers of the 1945 Constitution from the beginning have realized that for the sake of efficiency and effectiveness of government administration and in order to achieve maximum results in the management of the State, the State of Indonesia is divided into large and small regions. These thoughts are clearly reflected in Article 18 of the 1945 Constitution namely, "The division of the Indonesian region over large and small regions with the form and composition of the government is stipulated by the law by considering and remembering the basis of deliberation in the system of state governance and the rights of origin in the regions are special".

Substantially the 1945 Constitution has stipulated the existence and regulation of local governments and arrangements related to relations between levels of local government in Indonesia. According to Marbun (2005), that "If we elaborate more deeply, the substance of the 1945 Constitution and its explanation has clearly stipulated how the arrangement of a regional government and the arrangement of mutual relations and the position of relations in the NKRI system. Indirectly, it has been 
described the structure and pattern of local government organizations in many ways constitutes a translation of the organizational structure and mechanism of the NKRI organization in a limited sense. The description is as follows:

- Local government is a necessity in the structure of the Republic of Indonesia

- Regional governments have regional heads

- Governments in the regions are run in a democratic manner with "jointed on the basis of deliberation" This has become the basic foundation of the embryo for the establishment of regional legislative institutions which subsequently develop and become DPRD institutions

- The regions are given autonomous principles

- Establishment of an area is determined by a law

- The provision of autonomy is adjusted to the situation and condition of the region concerned

The deconcentration principle of Act Number 5 of 1974: During the New Order government, Law No. 5 of 1974 concerning the Principles of government in the region was issued, consisting of 8 chapters with 94 articles. In connection with the principle of deconcentration, Law No. 5 the Year 1974 article 1 point (f), stated that, "Deconcentration is the delegation of authority from the government or the Regional Head or the Head of the Vertical Agency at the top level to officials in the region".

Based on the studies above, the deconcentration principle is the delegation of authority from the central government, regional head or vertical agency to its elements/officials in the region, so that, the recipient of delegation of non-regional authority will but certain elements which in this case, they are the representatives of central government/officials in regions such as governors, regents, mayors and camats and vertical agencies. Whereas those who can delegate authority are the central government, regional heads and top-level vertical agencies. Such as from the central government to the governor, from the governor as the regional head to the regent/mayor.

Vertical institutions based on Article 1 point (h) of Law No. 5 the Year 1974, are equipment from non-departmental government departments or agencies that have a working environment in the region concerned. Vertical agencies are elements of departmental or non-departmental government institutions that have work environments in the region concerned, so that, vertical agency can carry out central government affairs in the regions. In the framework of implementing the principle of deconcentration in the territory of Indonesia, it is divided into provinces and capitals of the state as stated in Article 72 of Law No. 5 the Year 1974, namely: in the framework of implementing the deconcentration principle, the territory of the unitary state of the Republic of Indonesia is divided into provinces and capitals of the country. The province's territory is divided into districts and municipalities. District and municipal areas are divided into sub-districts. If deemed necessary in accordance with its growth and development in the district area an administrative city can be established whose regulation is determined by legislation.

Based on Article 73 of Law No. 5 the Year 1974, that "If deemed necessary, the Minister of Home Affairs can appoint an assistant governor assistant district head or mayor who has a particular work area in the context of deconcentration. In this Act in the region can be appointed assistant governor, regent assistant or assistant mayor by the minister of the interior with the aim as an element that carries out the principle of deconcentration in the region, so that, central government affairs in the region can be assisted by assistants of governors, district assistants and mayor of mayor.

Each region is led by a Regional Head as stated in article 76 of Law No. 5 Year 1974, namely, "Every Territory is led by a Regional Head". Regional Head in the area starting from the governor to the camat as stated in article 77 of Law No. 5 of 1974, namely, Head of Region:

- Province and national capital are called governors

- The district is called the regent

- The municipality is called waliotamadya

- The administrative city is called the Mayor

- The sub-district is called the camat

The camat also functions as the head of the region who has the authority as the sole ruler in his working area, so that, the camat is assigned as administrator of government, development and community. The existence of the regional head also concurrently as regional head can be seen in Article 79 of Law No. 5 the Year 1974 which states that:

- The Head of the Level I Region because his position is the head of the province or the capital of the State

- The Head of the Level II Region because of his position is the Head of the Regency or Municipality Region

- Provisions concerning the appointment and dismissal of the Administrative City Head and the Sub-district Head are regulated by the Minister of Home Affairs Regulation 
The existence of the regional head also doubles as the head of the region, so that, the Head of the level 1 Region because of his position is the head of the province or the capital of the state. The Head of the level 2 Region because of his position is the Head of the Regency or Municipality Region. The position of Regional Head in the regional government is very strong and strategic, this can be seen in Article 80 of Law No. 5 the Year 1974, that "The Head of Region as the Representative of the Government is the Single Ruler in the field of government in his territory in the sense of leading the government, coordinating development and fostering the life of the community in all fields".

The regional head also serves as the head of the region, so, the regional head is directly the central government representative in the region. As the representative of the central government gives authority to the head of the region as the sole ruler in his territory in the sense that the head of the region presides over the government, coordinates the development and fosters the life of the community in all fields in his territory. In addition to the Regional Head, the central government officials in the region are vertical agencies in delegating authority from the government to representatives of the central government in the regions through deconcentration principles. Vertical institutions based on Article 85 of Law No. 5 of 1974 are, "In carrying out its duties, the Head of Vertical Institutions is under the coordination of the relevant Regional Head".

Thus, in carrying out its duties the head of the vertical agency is under the coordination of the head of the relevant region because the regional head is an official or representative of the central government in the region.

The principle of deconcentration of the period of Law No. 22 the Year 1999: Deconcentration principle based on Article 1 paragraph (f) of Law No. 22, the Year 1999 is "The delegation of authority from the government to the Governor as the representative of the government and/or the central device in the region". Deconcentration is a delegation of authority from the central government to representatives of the central government in the region so that delegation of authority in the context of deconcentration is not delegated to regions such as decentralization but to officials or representatives of the central government in the region, it can be to the regional head in this case the governor and also to vertical agencies in the region. Based on Article 1 point (j) of Law No. 22 the Year 1999, the administrative area is, "Governor's working area as government representative".
Whereas vertical institutions based on Article 1 point (k) of Law No. 22 of 1999 are "equipment of departments and/or non-departmental government institutions in the regions". The delegation of authority in the context of deconcentration is delegated to the governor as the representative of the central government and can be delegated to vertical agencies in the region. In this Law the principle of deconcentration is only up to the provincial level, it is seen that only governors are declared as representatives of the central government while the regents and mayors are not represented as representatives of the central government, so that, the regents and mayors are only Regional Heads and Heads of Government. As stated in the explanation of Law No. 22 of 1999, namely "The implementation of the deconcentration principle is placed in the provincial area in its position as an administrative area to implement certain governmental authorities delegated to the governor as the government representative.

Elucidation of Law No. 22 the Year 1999, namely, "The regions that are formed based on the principles of decentralization and deconcentration are provincial areas while the regions that are formed based on the principles of decentralization are district and city areas". Thus, it can be clearly seen that the principle of deconcentration is only up to the provincial level in this case the Governor as the representative of the central government while the Regent and Mayor are only functioning as Regional Heads and not as representatives of the central government in the regions.

The principle of deconcentration of the period of Law No. 32 of 2004: Deconcentration principle plays a role in carrying out the duties of the central government in the region, the principle of deconcentration based on Article 1 point (8) of Law No. 32 Year 2004 concerning Regional Government is, "The delegation of governmental authority by the government to the Governor as the representative of the government and/or to certain vertical agencies". Based on Article 10 paragraph (4) of Law No. 32 of 2004, it is stated that, "In the framework of organizing governmental affairs (foreign policy, defense, security, justice, national and religious monetary and fiscal) the government organizes itself or can delegate part of government affairs to the government apparatus or government representatives in the region or can assign to the regional government and/or village government.

Article 12 paragraph (2) of Law No. 32 the Year 2004 states that "Government affairs submitted to the Governor are accompanied by funding in accordance with deconcentrated affairs". Regarding the existence of the 
governor as a representative of the central government in the region, Article 37 of Law No. 32 of 2004 is stated, namely:

- A governor who because of his position is also a government representative in the relevant province

- In his position as referred to in paragraph (1), the Governor is responsible to the President

In this Act, the governor was declared because his position as a representative of the government in the province but there was no mention of the position of deputy governor as a representative of the government, so that, the vice governor could not help and carry out the duties of the governor as a representative of the government such as representing the governor to appoint. The regent and mayor cannot be carried out by the deputy governor because inaugurating the regent and mayor in the governor's working area with the capacity as a representative of the government, the deputy governor is absent as the government's representative.

The governor as a government representative has its own duties and authorities as regulated in Article 38 of Law No. 32 of 2004 that:

- The Governor in his position as referred to in article 37 has the duty and authority

- Guidance and supervision of district/city regional government administration

- Coordination of the administration of provincial and district/city government affairs

- Coordination of guidance and supervision of the implementation of co-administration tasks in provincial and district/city regions

Funding of duties and authorities of the governor as referred to in paragraph (1) is charged to the State Budget. The financial position of the governor as referred to in paragraph (1) is regulated in government regulations. The procedure for implementing the governor's duties and authorities as referred to in paragraph (1) is regulated in government regulations.

Based on the explanation of Law No. 32 of 2004 this is, "The equipment of the department and/or non-departmental government institution that manages government affairs that are not submitted to regions in certain areas in the context of deconcentration". In this law, the principle of deconcentration only reaches the level of the provincial government while the regency/city only carries out the principle of decentralization and co-administration because none of the regents/mayors are represented as representatives of the central government in the region, meaning the capacity of the regent/mayor is only the regional head autonomous not as a representative of the government in the region. Follow-up on deconcentration principles is regulated in the Government Regulation of the Republic of Indonesia No. 7 of 2008 concerning deconcentration and co-administration.

The principle of deconcentration for the period of Law No. 23 the Year 2014: Based on Article 1 point (9) Law No. 23 of 2014 concerning regional government stated that, "Deconcentration is the delegation of a portion of governmental affairs which are the authority of the central government to the governor as a representative of the central government, to vertical agencies in certain regions and/or to governors and regents/mayors as responsible for general government affairs".

The principle of deconcentration is a form of delegation of part of governmental affairs which is the authority of the central government to the governor as a representative of the central government, to vertical agencies in certain regions and/or to governors and regents/mayors as responsible for general government affairs. In this Law, the deconcentration principle is only submitted to the governor as the representative of the central government and to vertical agencies for absolute affairs and concurrent affairs which are the authority of the central government while for general government affairs are delegated to the governor and also to the regent/mayor as head governance.

Based on Article 1 point (10) of Law No. 23 the Year 2014 , it is stated that vertical agencies are, "The apparatus of ministries and/or non-ministerial government agencies that administer government affairs that are not handed over to autonomous regions in certain areas in the context of deconcentration"

The existence of vertical agencies in the regions is to carry out tasks from non-ministerial government ministry institutions. The administrative area is the working area of the central government apparatus including the governor as the representative of the central government to administer governmental affairs which are the authority of the central government in the regions and the regent/mayor in carrying out general government affairs in the regions.

In connection with the principle of deconcentration in Article 10 paragraph (2) of Law No. 23 the Year 2014, it is stated that "In carrying out absolute governmental affairs as intended in paragraph (1) the central government: 
- Carry out alone

- Delegate authority to vertical agencies in the region or governors as representatives of the central government based on deconcentration principles

The principle of deconcentration in this Law is in the form of implementing absolute governmental affairs. In the implementation of the deconcentration principle, the central government can carry out these affairs alone or can delegate authority to vertical agencies in the region or governors as representatives of the central government based on deconcentration principles. In Article 19 paragraph (1) of Law No. 23 the Year 2014, it is stated that "Concurrent government affairs which are the authority of the central government are held:

- Alone by the central government

- By way of delegating to the governor as a representative of the central government or to vertical agencies in the region based on the principle of deconcentration or

- By assigning regions based on the principle of co-administration

It can be stated that in this Law concurrent government affairs which are the authority of the central government can be held by the central government alone and can also be delegated to the governor as a representative of the central government or to vertical agencies in the regions based on deconcentration principles or can also be carried out by assigning regions based on the principle of co-administration.

\section{CONCLUSION}

In general, the deconcentration principle is the delegation of authority from the government (central) to central government officials in the region or to vertical agencies in the region, so that, such authority remains the responsibility of the element that delegates authority.

Based on Law No. 5 the Year 1974, the deconcentration principle is a delegation of authority from several elements such as the central government, regional head or vertical agency elements to its elements/officials in the region, so that, the recipient of this delegation of authority is not but certain elements are representatives/central government officials in the area in this case the governor, regent, mayor and camat as well as vertical agency elements. While the elements that delegate authority are the central government, regional heads and top-level vertical agencies. Such as from the central government to the governor, from the governor as the regional head to the regent/mayor.
Based on Law No. 5 of 1974, it is stated that deconcentration is a form of devolution of authority from elements of the central government to its elements or representatives of the central government in the regions, so that, delegation of authority in the context of deconcentration is not delegated to regions such as decentralization but to government officials or representatives the center in the area can be to the regional head and also to vertical agencies in the region.

Based on Law No. 22 the Year 1999, it is stated that the deconcentration principle is a delegation of authority from the central government to its elements or representatives of the central government in the region, so that, delegation of authority in the context of deconcentration is not delegated to regions such as decentralization but to the central government official or representative in the region, it can be to the regional head in this case the governor and also to the vertical agencies in the region.

Based on Law No. 23 of 2014, it can be stated that the deconcentration principle is a delegation of authority from the government to the governor as the Representative of the central government and to vertical institutions in the region.

In connection with the concept of deconcentration principle in Law No. 23 of 2014 which states that the principle of deconcentration is only to governors and vertical agencies, so that, the governor is declared as the representative of the central government in the region to carry out the deconcentration principle while specifically for the affairs of general government stated in this Act authority is delegated to governors and regents/mayors but there is no stated that the regent/mayor as the Central Government Representative in the region to carry out the deconcentration principle specifically for the affairs of the general government, therefore, the deconcentration principle in this Law needs to be reviewed.

\section{ACKNOWLEDGEMENT}

Part of this study was conducted by using funding from the research projects of the XX-2018-008.

\section{REFERENCES}

Ali, M.N., M.R. Razman, Z. Ramli and K. Arifin, 2017. Understanding aggressive behaviour to avoid damages through the precautionary principle towards the Sustainable Development Goals (SDGs). J. Food Agric. Environ., 15: 52-55.

Emrizal and M.R. Razman, 2010. The study on international environmental law and governance: Focusing on the montreal protocol and the role of transboundary liability principle. Soc. Sci., 5: 219-223. 
Kertapraja, E.K., 2010. Regional Government: Political Configuration of Decentralization and Regional Autonomy: In the Past, now and the Challenges of Globalization. INNER, Jakarta, Indonesia, ISBN:9786029638103, Pages: 389 (In Indonesian).

Kertapraja, K., 2014. Policy on Decentralization and Regional Autonomy Originating from the 1945 Constitution. Yayasan Damandiri, Jakarta, Indonesia, (In Indonesian).

Khairil, M., M.R. Razman, Z. Ramli and K. Arifin, 2017. Understanding terrorism based on radicalism idea in order to avoid instability for achieving environmental peace and justice the Sustainable Development Goals (SDGs). J. Food Agric. Environ., 15: 48-51.

Marbun, B.N., 2005. DPRD and Regional Autonomy. Pustaka Sinar Harapan, Jakarta, Indonesia, (In Indonesian).

Razman, M.R. and A. Azlan, 2009. Safety issues related to Polychlorinated Dibenzo-p-Dioxins (PCDDs) and Polychlorinated Dibenzofurans (PCDFs) in fish and shellfish in relation with current Malaysian laws. J. Food Agric. Environ., 7 : 134-138.

Razman, M.R., 2014. Sale of goods act, 1957: The role of statutory implied terms towards food and environmental sustainability. Res. J. Appl. Sci., 9: 624-628.

Razman, M.R., 2015. A study on global financial mechanisms in the montreal protocol from environmental law and management perspectives. Int. Bus. Manage., 9: 111-116.

Razman, M.R., A.S. Hadi, J.M. Jahi, A.H.H. Shah and A.F. Mohamed et al., 2009a. The international law mechanisms to protect human habitat and environment: Focusing on the principle of transboundary liability. Int. Bus. Manage., 3: 43-46.

Razman, M.R., A.S. Hadi, J.M. Jahi, A.H.H. Shah and S. Sani et al., 2009b. A study on negotiations of the montreal protocol: Focusing on global environmental governance specifically on global forum of the united nations environmental programme. J. Food Agric. Environ., 7: 832-836.
Razman, M.R., A.S. Hadi, J.M. Jahi, A.H.H. Shah, S. Sani and G. Yusoff, 2010. A study on the precautionary principle by using interest approach in the negotiations of the montreal protocol focusing on international environmental governance and law. J. Food Agric. Environ., 8: 372-377.

Razman, M.R., A.S. Hadi, J.M. Jahi, K. Arifin and K. Aiyub et al., 2009c. The legal approach on occupational safety, health and environmental management: Focusing on the law of private nuisance and International Labour Organisation (ILO) decent work agenda. Int. Bus. Manage., 3: 4753.

Razman, M.R., M.B. Mokhtar, S.Z.S. Zakaria, K. Arifin and N.F.A. Bakar, 2014. The process of negotiations towards acceptance of the montreal protocol in Malaysia: Focusing on environmental management. Information (Japan), 17: $1255-1262$.

Razman, M.R., N.H. Nordin, M.B. Mokhtar, S.Z.S. Zakaria and K. Arifin et al., 2015. A study on packaged food safety in Kajang Municipal Council towards food and environmental sustainability. Information, 18: 521 536.

Rosidin, U., 2010. Regional Autonomy and Decentralization: Complete with Law No. 32 Year 2004 with Amendments. Pustaka Setia, Bandung, Indonesia, (In Indonesian).

Sarundajang, S.H., 2005. New Round of Regional Government Systems. Kata Hasta, Jakarta, Indonesia, ISBN:9789799947307, Pages: 374 (In Indonesian).

Sunindhia, Y.W. and N. Widiyanti, 1987. Practice of Organizing Government in the Region. Bina Aksara, Jakarta, Indonesia, Pages: 255 (In Indonesian).

Wasistiono, S., 2009. Improve the performance of the Regional Peoples Representatives Council (DPRD). Fokusmedia, Bandung, Indonesia, ISBN:9786028189668, Pages: 296.

Yudoyono, B., 2003. Regional Autonomy, Decentralization and Human Resource Development for Regional Government and DPRD Apparatus. Pustaka Sinar Harapan, Jakarta, Indonesia, (In Indonesian). 